\title{
KEGIATAN MENDAKI GUNUNG SEBAGAI MEDIA PENDIDIKAN KARAKTER
}

\author{
Alif Putra Lestari \\ SMA Muhammadiyah 10 Surabaya
}

\begin{abstract}
Abstrak: Pendidikan harus mampu menghasilkan individu berpengetahuan, terampil, dan mempunyai sikap yang baik. Selama ini pendidikan lebih berfokus pada tujuan kognitif berupa angka, sedangkan aspek sikap belum tersentuh secara optimal. Perlu inovasi pembelajaran yang menghasilkan individu yang berkarakter, mempunyai sikap yang baik untuk hidup di masyarakat. Penelitian ini bertujuan untuk mengetahui aspek sikap yang tumbuh selama kegiatan mendaki gunung. Penelitian ini merupakan penelitian deskriptif, data dikumpulkan dengan metode observasi partisipasi dan studi kepustakaan. Lokasi penelitian di Gunung Pundak Mojokerto, dengan siswa Pecinta Alam sebagai subjeknya. Sikap yang diamati adalah sikap menonjol pada diri para peserta selama kegiatan mendaki gunung. Hasil penelitian menunjukkan bahwa kegiatan mendaki gunung dapat menumbuhkan sikap baik pada diri peserta didik. Beberapa sikap yang tumbuh adalah sikap perencanaan, kerja sama, tanggung jawab, menghormati, kebersamaan, bersyukur, jujur, peduli, berani, tangguh, toleransi, dan sikap waspada. Bagi peneliti selanjutnya, perlu pengembangan model kegiatan untuk menghasilkan individu yang lebih lengkap yang berkarakter.

Kata kunci: mendaki gunung, sikap, pendidikan karakter
\end{abstract}

Abstract : Education must be able to produce knowledgeable, skilled, and have good attitudes. So far, education focus on cognitive goals, while the aspects of attitude have not been optimally touched. This study aims to determine the aspects of attitude that grow during mountain climbing activities. This research is a descriptive study, the data were collected by means of participatory observation and literature study. The research location is on Mount Pundak, Mojokerto, with Nature Lovers students as the subjects. The attitudes that were observed were the prominent attitudes of the participants during mountain climbing activities. The results showed that mountain climbing activities can foster good attitudes in students. Some of the attitudes that have grown are the attitude of planning, cooperation, responsibility, respect, togetherness, gratitude, honesty, caring, courage, resilience, tolerance, and vigilance. For further researchers, it is necessary to develop an activity model to produce a more complete individual with character.

Keywords : mountain climbing, attitude, character building

\section{A. PENDAHULUAN}

Setiap lembaga pendidikan harus mampu mencetak individu yang kaya akan pengetahuan, terampil, serta mempunyai sikap dan tindakan yang baik. Peraturan Kemdikbud RI No 37 (2018) menjelaskan bahwa tujuan kurikulum nasional mencakup empat kompetensi yaitu sikap spiritual, sikap sosial, pengetahuan, dan keterampilan. Setiap kegiatan pembelajaran diharapkan mampu menaungi empat kompetensi tersebut. Individuyang dihasilkan tidak hanya pandai menghafal teori, tetapi juga harus bisa hidup di tengah kelompok atau masyarakat. Kondisi demikian 
dibutuhkan dalam kehidupan yang kompleks saat ini, di tengah arus perkembangan zaman.

Beberapa temuan di lapangan menunjukkan bahwa kompetensi sikap belum sepenuhnya diperhatikan. Proses pembelajaran masih berfokus pada ranah pengetahuan dan keterampilan sebagai aspek yang harus didapatkan peserta didik. Hanya sedikit model atau metode pembelajaran yang mengedepankan aspek sikap sebagai tujuan akhir dari proses pembelajaran (Huda, 2016). Sikap tidak peduli, sikap tidak menghormati, sikap tidak jujur, sikap tidak bertanggung jawab merupakan contoh yang mudah ditemui di lingkungan sekolah atau sejenisnya. Hal demikian menunjukkan perlu penguatan aspek sikap dalam pembelajaran baik melalui, metode, model pembelajaran, ataupun media yang digunakan.

Sikap keseharian sebagai peserta didik ataupun yang sudah tidak menjadi peserta didik adalah cerminan kondisi pendidikan kita. Lembaga pendidikan menjadi faktor penting dalam mengembangkan sikap yang baik bagi peserta didiknya, sedangkan saat ini orientasi pendidikan masih berupa angka yang tertuang dalam raport atau hasil ujian (Imtihan dkk., 2017). Kondisi demikian berarti bahwa aspek sikap belum digarap secara optimal. Perlu adanya kegiatan yang mewadahi aspek sikap, sehingga terwujud keseimbangan dalam penguasaan ranah kognitif, psikomotor, dan afektif.

Perlu adanya inovasi melalui rancangan pembelajaran yang dapat menjadi media pendidikan karakter. Setiap mata pelajaran perlu melaksanakan kegiatan pembelajaran yang memberikan pengaruh baik dalam perkembangan sikap peserta didik (Muhtadi, 2016). Termasuk pada mata pelajaran geografi yang banyak bersinggungan dengan lingkungan sekitar. Mata pelajaran geografi punya banyak peluang untuk merancang kegiatan pembelajaran untuk pengembangan sikap peserta didik.

Salah satunya melalui kegiatan mendaki gunung, dimana peserta didik mendapatkan kesempatan langsung untuk terjun ke alam. Menurut (Sukmaliah dkk., 2018) selain mengaplikasikan teori, peserta didik juga mendapatkan kesempatan langsung untuk mempersiapkan kebutuhan, merencanakan perjalanan, berinteraksi dengan temannya, memecahkan masalah, dan lebih peka terhadap lingkungan sekitar. Hal demikian yang perlu ditanamkan sejak awal pada peserta didik sebagai bekal untuk kehidupan mereka kelak, sebagai modal menjadi individu yang berkarakter. Kegiatan mendaki gunung sangat tepat dijadikan sebagai 
media pendidikan karakter. Penelitian ini bertujuan untuk mengetahui mengetahui ranah sikap yang didapatkan peserta didik selama kegiatan mendaki gunung.

\section{B. METODE}

Penelitian ini merupakan jenis penelitian deskriptif. Karakter yang dimaksud dalam penelitian ini adalah sikap pada diri peserta didik. Penelitian ini menggambarkan sikap yang tumbuh pada diri peserta didik melalui kegiatan mendaki gunung. Mulai tahap awal hingga akhir kegiatan pendakian akan dianalisis secara mendalam, beberapa sikap yang dapat berkembang pada diri peserta didik yang mengikuti kegiatan. Metode pengumpulan data menggunakan teknik observasi pasrtisipasi dan studi kepustakaan dari beberapa literatur.

Kegiatan penelitian dilakukan dengan pendampingan penuh mulai dari persiapan hingga selesai kegiatan pendakian. Kegiatan endakian dilaksanakan pada bulan April tahun 2019 di Gunung Pundak, Kecamatan Trawas, Kabupaten Mojokerto. Kegiatan diikuti oleh 20 peserta didik yang tergabung dalam komunitas pecinta alam SMA Muhammadiyah 10 Surabaya. Sejak tahap perencanaan hingga berakhirnya kegiatan, sepenuhnya dikendalikan oleh peserta didik, termasuk penentuan lokasi, penentuan, transportasi, dan isi kegiatan. Selama tahap itulah penulis melakukan observasi sikap-sikap yang paling menonjol yang dapat dilihat dari diri setiap peserta. Pada akhirnya akan didapatkan kesimpulan yang diperkuat dengan studi kepustakaan..

Data dianalisis dengan metode deskriptif kualitatif. Analisis menggunakan model Miles dan Huberman dengan tahapan reduksi, penyajian, dan verifikasi. Reduksi merupakan kegiatan merangkum, memilih hal-hal pokok, memfokuskan pada hal-hal yang penting, dan mencari tema dan polanya. Data yang sudah direduksi dan tersusun selanjutnya akan disajikan. Sedangkan verifikasi merupakan hasil penelitian yang menjawab fokus penelitian berdasarkan hasil analisis data. Menurut Gunawan (2013) reduksi data, penyajian data, dan penarikan kesimpulan atau verifikasi menjadi gambaran keberhasilan secara berurutan sebagai rangkaian kegiatan analisis yang saling susul menyusul.

\section{HASIL DAN PEMBAHASAN}

\section{C.1. HASIL}

Kegiatan pembelajaran dapat dilaksanakan di dalam maupun di luar kelas. Semuanya menyesuaikan tema bahan kajian atau metode yang digunakan oleh pendidik untuk mencapai tujuan pembelajaran yang diinginkan. Sementara itu pembelajaran di luar kelas sangat diperlukan sebab selama ini sebagian besar kegiatan pembelajaran 
dilaksanakan di dalam kelas (Andini, 2018). Hal ini sebagai penyeimbang supaya peserta didik tidak jenuh berada di kelas dalam waktu yang lama. Menurut Mernisa \& Djukri (2018) pembelajaran di luar kelas sangat sesuai untuk menumbuhkan karakter yang baik pada diri peserta didik. Mereka akan mendapatkan pengalaman langsung di lapangan, mereka akan lebih banyak berinteraksi dengan teman, dengan gurunya, atau bahkan dengan orang lain di sekitarnya. Kondisi demikian akan menumbuhkan sikap-sikap yang baik, yang diperlukan bagi mereka sebagai peserta didik.

\section{Hasil Pengamatan Sikap Kegiatan Mendaki Gunung}

\begin{tabular}{cll}
\hline No. & \multicolumn{1}{c}{ Aspek sikap } & \multicolumn{1}{c}{ Keterangan } \\
\hline 1 & Penuh perencanaan & $\begin{array}{l}\text { Seluruh peserta terlibat dalam perencanaan } \\
\text { kegiatan dari awal hingga akhir }\end{array}$ \\
\hline 2 & Kerjasama & Saling membagi tugas untuk persiapan \\
\hline 3 & Tanggung jawab & $\begin{array}{l}\text { Komitmen para peserta menjalankan tugasnya } \\
\text { masing-masing hingga kegiatan selesai }\end{array}$ \\
\hline 4 & Menghormati & $\begin{array}{l}\text { Peserta mampu menghormati orang lain yang } \\
\text { mereka temui selama pendakian }\end{array}$ \\
\hline 5 & Kebersamaan & Sejak awal ditanamkan bahwa apapun yang \\
& & terjadi mereka harus bersama-sama \\
\hline 6 & Bersyukur & Menuju puncak secara spontan mereka mengucap \\
& & syukur atas apa yang dilihatnya \\
\hline 7 & Jujur & $\begin{array}{l}\text { Peserta didik sangat tidak diperkenankan } \\
\text { berbohong selama pendakian }\end{array}$ \\
\hline 8 & Peduli & Saling berbagi bekal satu dengan yang lain \\
\hline 9 & Berani & $\begin{array}{l}\text { Peserta didik berani mengambil keputusan } \\
\text { terutama ketua pendakian }\end{array}$ \\
\hline 10 & Tangguh & Peserta didik tidak boleh mengeluh, selalu \\
& & gembira selama perjalanan \\
\hline 11 & Toleransi & Menghargai perbedaan pendapat dengan sesama \\
\hline 12 & Waspada & $\begin{array}{l}\text { Peserta didik berhati-hati selama pendakian } \\
\text { karena berada di alam bebas }\end{array}$ \\
& &
\end{tabular}

Hasil obervasi di atas dilaksanakan selama kegiatan pendakian berlangsung. Pengamatan yang dilakukan menemukan sikap-sikap

didik yang mengikuti kegiatan. Beberapa sikap pada tabel 1 tersebut merupakan hasil pengamatan sejak tahap persiapan 
hingga berakhirnya kegiatan pendakian.

Semua sikap yang muncul merupakan pengaruh langsung dari kegiatan mendaki gunung yang memang ditujukan untuk membentuk karakter peserta didik.

Kegiatan pembelajaran luar kelas mampu merangsang tumbuhnya nilai-nilai karakter (Nisa, 2015). Selama tahap perencanaan hingga berakhirnya kegiatan pendakian peserta berinteraksi secara intens dengan sesama peserta, dengan guru, dengan orang lain yang terkait. Seperti halnya ketika berada di Gunung Pundak, dimana mereka bertemu dengan orang yang belum pernah mereka temui sebelumnya. Mereka juga dipaksa bagaimana berinteraksi dengan alam bebas, dengan hutan dan sungai yang mereka lewati sepanjang perjalanan pendakian.

\section{C.2. PEMBAHASAN}

Sebelum kegiatan mendaki dilaksanakan, seluruh peserta secara bersama melakukan perencanaan, mulai dari penentuan waktu, tempat pendakian, peralatan dan perlengkapan, akomodasi, persiapan fisik, hingga menentukan tujuan akhir kegiatan. Berawal dari sini peserta didik melakukan perencanaan yang matang, perhitungan waktu, perhitungan biaya, perhitungan bekal yang dibawa, dan sebagainya. Sikap merencanakan terlihat dengan jelas sebagai individu maupun kelompok sebab dalam kegiatan pendakian terdapat kebutuhan individu dan kelompok. Menurut Taufik dkk. (2018), kemandirian dalam mengorganisir merupakan bagian dari pembelajaran yang sangat penting.

Kepanitiaan yang dibentuk oleh mereka akhirnya membuat individu punya tugas masing-masing. Setiap individu bekerja sama dengan yang lain untuk menyukseskan kegiatan, saling melengkapi satu dengan yang lainnya. Menurut Nurasiah (2019) seseorang yang memiliki sikap sosial terlihat dari adanya kerja sama. Peserta didik belajar mengelola kemampuan yang dimiliki para peserta untuk dijadikan suatu kesatuan. Masing-masing peserta didik bertanggung jawab penuh dengan tugasnya sesuai dengan pembagian di awal. Sementara ketua penitia mempunyai tugas untuk mengingatkan anggotanya terkait tugas yang diemban. Kondisi demikian semakin menguatkan sikap kerja sama dan tanggung jawab pada diri peserta didik.

Selama kegiatan pendakian dari awal hingga akhir peserta didik banyak menemui orang asing yang tidak mereka kenal. Seluruh peserta sepakat untuk menyapa siapapun yang ditemui selama pendakian, serta bersikap hormat terlebih kepada orang yang lebih tua. Peserta juga 
harus selalu bersama selama perjalanan menuju puncak, tidak boleh ada yang mendahului dan tidak ada yang ditinggal dibelakang. Jika waktunya makan semua harus makan, tidak boleh ada yang makan terlebih dahulu ataupun makan belakangan. Semua bekal yang dibawa juga dijadikan satu sebagai milik bersama, dimasak bersama, kecuali obat pribadi. Sehingga seluruh peserta menjadi lebih kompak dan merasa memiliki antara satu dengan yang lain, menguatkan kebersamaan. Senada dengan pernyataan Rahman dkk., (2018) bahwa kegiatan pendakian menjadi sarana pembentukan karakter, menambah teman, dan bersosialisasi.

Salah satu aspek yang sangat penting dalam ranah sikap religi adalah rasa bersyukur. Salah satu faktor kegiatan mendaki gunung adalah supaya peserta didik lebih dekat dengan alam, lebih dekat dengan Sang Pencipta melalui pengenalan akan ciptaan-ciptaanNya. Sepanjang perjalanan dari pos perizinan hingga ke puncak para peserta melihat banyak hal yang belum pernah mereka temui, atau melihat pemandangan yang membuat mereka takjub. Seorang pecinta alam akan menemukan makna hidupnya ketika mendaki dan dekat dengan alam, sehingga dapat meningkatkan kecerdasan spiritualnya (Saputra, 2017). Sehingga secara spontan akan muncul respon berupa kalimat ucapan syukur kepada Tuhan Yang Maha Esa akan kebesaranNya yang menciptakan alam begitu indah. Ataupun berupa pertanyaan-pertanyaan yang mereka munculkan yang tidak membutuhkan jawaban, sebab hanya sebagai konfirmasi mereka akan kebesaran Tuhan.

Ada lontaran dari peserta yang menyatakan bahwa selama di gunung tidak boleh berbohong, nanti akan kualat . Sekilas terlihat sepele namun punya manfaat yang besar sebab pada hakikatnya memang sebagai manusia kita tidak boleh berbohong, dimanapun itu tempatnya. Alhasil sejak awal keberangkatan hingga kembali ke sekolah peserta didik berupaya untuk tidak berbohong sedikitpun. Kebiasaan demikian jika diteruskan akan menjadi sesuatu yang baik pada diri peserta didik, sebab salah satu indikator peserta didik itu berkarakter adalah sikapnya yang selalu jujur. Selaras dengan pernyataan (Kadir, 2015) bahwa sikap yang baik perlu dimiliki oleh peserta didik.

Seluruh peserta pendakian juga akan lebih peduli terhadap sesama, peduli terhadap lingkungan di mana mereka berada. Ada perjanjian tidak tertulis di antara peserta yaitu selalu memperhatikan kondisi peserta yang lain, tidak boleh ada yang lewat diperhatikan. Hal ini bertujuan untuk 
memastikan bahwa seluruh peserta dalam kondisi aman, dan tetap sehat. Selain itu mereka juga dituntut oleh pembina mereka untuk peduli terhadap lingkungan, mereka tidak membuang sampah sembarangan, bahkan sebaliknya mereka melakukan pembersihan sampah plastik di sepanjang perjalanan.

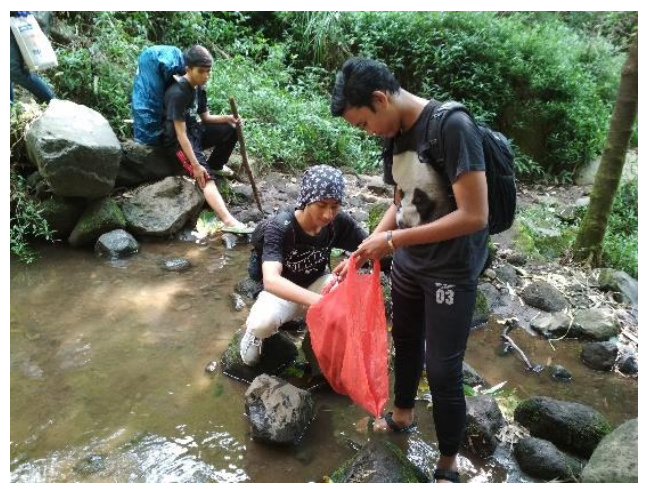

Peserta memungut sampah plastik di sungai yang mereka lewati

Gambar di atas merupakan aktivitas peserta pendakian saat mereka melewati sungai, mereka langsung memunguti sampah plastik yang berada di sungai dan sekitarnya. Mereka juga tidak merusak atau menebang pohon sembarangan, bahkan memetik daun sembarangan pun tidak. Hasil penelitian Rasmilah (2016) menunjukkan bahwa outdoor study dapat meningkatkan sikap kepedulian peserta didik terhadap lingkungan.

Sikap berani juga tumbuh dari kegiatan pendakian ini, sebab mereka berada di alam bebas. Para peserta adalah anak kota yang sejak kecil tumbuh di tengah fasilitas kehidupan yang memadai, tapi kali ini mereka dipaksa untuk hidup di alam bebas. Berjalan melewati hutan, tidur tanpa penerangan, dengan kondisi di puncak yang sangat dingin. Keberanian hidup apa adanya ini menjadi penting bagi peserta didik, supaya mereka tidak bergantung pada apapun seperti sedianya mereka hidup di tengah kota. Sikap berani merupakan bagian dari karakter yang dibutuhkan oleh generasi muda (Asa, 2019).

Masing - masing peserta berkewajiban untuk terus memberi semangat peserta lain jika tampak mulai kelelahan, terutama ketua rombongan. Hal demikian melatih para peserta untuk menjadi individu yang tangguh, tidak manja, mengoptimalkan kekuatan yang dimiliki untuk mencapai tujuan. Menurut Rahman dkk. (2017) aktivitas mendaki gunung sebagai sarana melatih fisik dan relaksasi fisik.

Selama perjalanan tidak dapat dipungkiri akan banyak terjadi perdebatan karena perbedaan pandangan antara peserta satu dengan yang lain. Saling menghargai pendapat yang lain diwajibkan untuk seluruh peserta, karena bagaimanapun semua harus keputusan bersama. Kerelaan berbagi ruang dengan pendapat yang berbeda yang akan menumbuhkan sikap toleransi pada diri peserta didik. 
Tujuan pendidikan karakter yaitu mengantarkan peserta didik mempunyai kepribadian dan nilai-nilai karakter mulia, seperti religius, jujur, toleransi, disiplin, kerja keras, kreatif, mandiri, demokratis, cinta tanah air, menghargai prestasi, bersahabat, cinta damai, peduli lingkungan, peduli sosial, dan tanggung jawab Zafirah dkk., (2018). Selain itu, mereka juga siap membantu pendaki lain yang membutuhkan pertolongan tanpa melihat perbedaan suku, ras, maupun agama. Sikap seperti ini sangat penting bagi peserta didik untuk dapat hidup berdampingan dengan masyarakat.

Sikap terakhir yang diamati adalah waspada, yaitu kehati-hatian peserta dalam membuat keputusan atau selama perjalanan menuju puncak. Salah satu tujuan pembelajaran di luar kelas adalah mendidik peserta mampu berfikir kritis dan tepat dalam mengambil keputusan (Purnomo, 2015). Keputusan yang diambil peserta harus matang karena mereka sedang berada di alam bebas.

Pembelajaran di luar kelas terbukti memberikan kontribusi besar terhadap perkembangan sikap peserta didik (Yıldırım \& Akamca, 2017). Beberapa sikap tersebut merupakan aspek penting dalam sebuah pendidikan karakter. Mereka menjadi individu dengan kepribadian yang baik, itulah yang dibutuhkan oleh sebuah bangsa tidak hanya yang pandai tapi juga mempunyai sikap yang baik. Setiap tindakan tidak hanya berdasar pada pengetahuan, tetapi juga keputusan moral yang harus dibiasakan terus menerus. Kewajiban lembaga pendidikan adalah menghasilkan individu yang berpengetahuan dan mempunyai sikap yang baik.

\section{KESIMPULAN}

Kegiatan mendaki gunung oleh peserta didik dapat menumbuhkan beberapa sikap baik pada diri peserta didik. Selama kegiatan mendaki gunung seluruh peserta dirangsang dan dikondisikan untuk mengasah sikapsikap yang dianggap penting sebagai seorang peserta didik. Peserta menjadi lebih penuh perencanaan, bekerja sama, tanggung jawab, menghormati, tumbuh kebersamaan, bersyukur, jujur, lebih peduli, berani, tangguh, toleransi, dan lebih waspada. Sikap-sikap yang tumbuh selama kegiatan mendaki gunung tersebut menjadi bekal yang baik sebagai individu yang berkarakter. Bagi peneliti selanjutnya, perlu pengembangan model kegiatan pembelajaran luar kelas untuk menghasilkan individu yang lebih berkarakter. 


\section{DAFTAR PUSTAKA}

Andini, N. F. (2018). Pengaruh Pembelajaran Outdoor Study Terhadap Sikap Kepedulian Lingkungan Bagi Mahasiswa S1 Pendidikan Geografi STKIP Ahlussunah Bukittinggi. Jurnal Kepemimpinan Dan Pengurusan Sekolah, 3(2), 109-118.

Asa, A. I. (2019). PENDIDIKAN KARAKTER MENURUT KI HADJAR DEWANTARA DAN DRIYARKARA. Jurnal Pendidikan Karakter, 9(2), 245258.

Gunawan, I. (2013). METODE PENELITIAN KUALITATIF. In Pendidikan (p. 143). Universitas Negeri Malang. http://fip.um.ac.id/wpcontent/uploads/2015/12/3_Metpen -Kualitatif.pdf

Huda, M. (2016). Implementasi Evaluasi Hasil Belajar Pendidikan Agama Islam Ranah Afektif di SMPN 1 Tanara Serang Banten [UIN Syarif Hidyataullah Jakarta]. http://repository.uinjkt.ac.id/dspace /handle/123456789/33140

Imtihan, N., Zuchdi, D., \& Istiyono, E. (2017). Analisis Problematika Penilaian Afektif Peserta Didik Madrasah Aliyah. Schemata: Jurnal Pascasarjana IAIN Mataram, $\quad 6(1), \quad 63-80$. https://journal.uinmataram.ac.id/in dex.php/schemata/article/download /836/465/
Kadir, S. F. (2015). Strategi Pembelajaran Afektif Untuk Investasi Pendidikan Masa Depan. Jurnal Al-Ta'dib, 8(2), 135-149.

Kemdikbud RI. (2018). Permendikbud RI Nomor 37 tahun 2018 tentang Perubahan atas Peraturan Menteri Pendidikan dan Kebudayaan Nomor 24 tahun 2016 tentang Kompetensi Inti dan Kompetensi Dasar Pelajaran pada Kurikulum 2013 pada Pendidikan Dasar dan Pendidikan Menengah. JDIH Kemendikbud, 2025, 1-527.

Mernisa, M., \& Djukri. (2018). PENGARUH PENERAPAN OUTDOOR LEARNING PROCESS ( OLP ) TERHADAP PEMAHAMAN KONSEP DAN SIKAP PEDULI LINGKUNGAN SISWA SMA PADA MATERI EKOSISTEM. Jurnal Nalar Pendidikan, 6(2), 128-135.

Muhtadi, A. (2016). Pengembangan Sikap dan Perilaku Siswa yang Bermoral dalam Kegiatan Pembelajaran di Sekolah. FIP UNY; Kurikulum Dan Teknologi Pendidikan, 20.

Nisa, J. (2015). Outdoor Learning Sebagai Metode Pembelajaran Ips Dalam Menumbuhkan Karakter Peduli Lingkungan. SOSIO DIDAKTIKA: Social Science Education Journal, 2(1), 1-11. https://doi.org/10.15408/sd.v2i1.13 39

Nurasiah, S. (2019). Meningkatkan Sikap Sosial Melalui Penerapan Model 
Pembelajaran Value Clarification

Technique. Al-Aulad: Journal of

Islamic Primary Education, 2(1), 84-92. https://doi.org/10.15575/alaulad.v2i1.4435

Purnomo, A. (2015). PENGARUH PEMBELAJARAN OUTDOOR TERHADAP PENGETAHUAN, DAN SIKAP PELESTARIAN LINGKUNGAN MAHASISWA S1 PENDIDIKAN GEOGRAFI UNIVERSITAS KANJURUHAN MALANG. JURNAL

PENDIDIKAN GEOGRAFI, 20(1), 951-952.

Rahman, F. A., Kristiyanto, A., \& Sugiyanto. (2017). Motif, Motivasi,

Dan Manfaat Aktivitaspendakian Gunung Sebagai Olahraga Rekreasi Masyarakat. Multilateral Jurnal Pendidikan Jasmani Dan Olahraga, 16(2), 143-153. https://doi.org/10.20527/multilater al.v16i2.4251

Rahman, F. A., Sugiyanto, \& Kristyanto, A. (2018). Mountaineering physical activities as community recreational sports. Jurnal Pendidikan: Teori, Penelitian, \& Pengembangan, 3(3), 398-405.

Rasmilah, I. (2016). Pembelajaran Outdoor Study Untuk Membentuk Kepedulian Lingkungan. Jurnal Geografi Gea, 13(1), 85-91. https://doi.org/10.17509/gea.v13i1. 3312

Saputra, D. (2017). Kecerdasan Spiritual

Pada Mahasiswa Pecinta Alam [Universitas Muhammadiyah
Surakarta].

http://eprints.ums.ac.id/id/eprint/53 972

Sukmaliah, neneng E., Amalia, A. R., \& Neneng, A. S. (2018). METODE OUTDOOR STUDY UNTUK MENINGKATKAN

KETERAMPILAN DASAR KECERDASAN SOSIAL. Jurnal ADHUM, VIII(1), 1-26.

Taufik, A., Subarjah, H., Supriyadi, T., \& Fauzi, R. A. (2018). PENGARUH KEGIATAN PEMBELAJARAN OUTDOOR EDUCATION TERHADAP SIKAP KEMANDIRIAN SISWA DALAM PENDIDIKAN JASMANI. Jurnal PGSD UPI, 171-180.

Yıldırım, G., \& Akamca, G. Ö. (2017). The effect of outdoor learning activities on the development of preschool children. South African Journal of Education, 37(2), 1-10. https://doi.org/10.15700/saje.v37n $2 \mathrm{a} 1378$

Zafirah, A., Agusti, F. A., Engkizar, Anwar, F., Alvi, A. F., \& Ernawati. (2018). Penanaman nilai-nilai karakter terhadap peserta didik Melalui permainan congkak sebagai media pembelajaran. Jurnal Pendidikan Karakter, 8(1), 95-104. https://doi.org/10.21831/jpk.v8i1.2 1678 